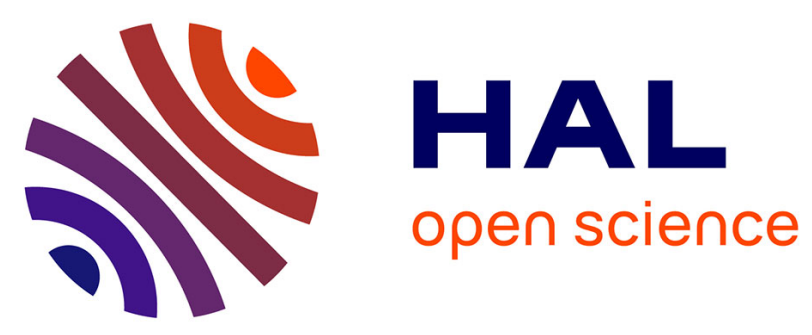

\title{
A cross-section analysis of sedimentary organic matter in a mangrove ecosystem under dry climate conditions: The Somone estuary, Senegal
}

I. Sakho, V. Mesnage, Yoann Copard, Julien Deloffre, G. Faye, R. Lafite, I. Niang

\section{To cite this version:}

I. Sakho, V. Mesnage, Yoann Copard, Julien Deloffre, G. Faye, et al.. A cross-section analysis of sedimentary organic matter in a mangrove ecosystem under dry climate conditions: The Somone estuary, Senegal. Journal of African Earth Sciences, 2015, 101, pp.220-231. 10.1016/j.jafrearsci.2014.09.010 . insu-01093950

\section{HAL Id: insu-01093950 \\ https://hal-insu.archives-ouvertes.fr/insu-01093950}

Submitted on 24 Mar 2015

HAL is a multi-disciplinary open access archive for the deposit and dissemination of scientific research documents, whether they are published or not. The documents may come from teaching and research institutions in France or abroad, or from public or private research centers.
L'archive ouverte pluridisciplinaire HAL, est destinée au dépôt et à la diffusion de documents scientifiques de niveau recherche, publiés ou non, émanant des établissements d'enseignement et de recherche français ou étrangers, des laboratoires publics ou privés. 


\title{
A cross-section analysis of sedimentary organic matter in a mangrove ecosystem under dry climate conditions: The Somone estuary, Senegal
}

\author{
Issa Sakho ${ }^{\text {a, c }}$ \\ Valérie Mesnage ${ }^{\mathrm{a}}$ \\ Yoann Copard ${ }^{\text {ad }}$ \\ Julien Deloffre ${ }^{a}$ \\ Guilgane Faye \\ Robert Lafite $^{\mathrm{a}}$ \\ Isabelle Niang ${ }^{\mathrm{c}}$ \\ ${ }^{a}$ Laboratoire de Morphodynamique Continentale et Côtière, Université de Rouen, UMR \\ CNRS 6143, 76821 Mont-Saint Aignan, Cedex, France \\ ${ }^{\mathrm{b}}$ Département de Géographie, Faculté des Lettres et Sciences Humaines, Université \\ Cheikh Anta Diop de Dakar, Senegal \\ ${ }^{c}$ Département de Géologie, Faculté des Sciences et Techniques, Université Cheikh Anta \\ Diop de Dakar, Senegal \\ ${ }^{\mathrm{d}}$ UMR CNRS 7327 ISTO, 45071 Orléans Cedex 2, France
}

\begin{abstract}
Mangrove sediments are an important organic matter (OM) reservoir and play a major role in the carbon cycle. Since the 1990s, these ecosystems were subjected to numerous studies, in order to quantify the sedimentary sink for organic carbon (OC) and to characterize the organic matter sources, but remain poorly studied in Western Africa. The aim of our study is to quantify the organic carbon content and to identify the OM origin stored in the Somone mangrove sediments. Studied area is characterized by a (i) dry climate conditions with a higher rate of evaporation, (ii) lack of freshwater input by river, and (iii) tide dominated system. Here, we focus on physico-chemical properties of sediments (temperature, $\mathrm{pH}$ and redox), sediment grain size, water content, particulate organic carbon and dissolved organic carbon from a series of $40 \mathrm{~cm}$-deep cores in four tidal contexts: mudflat, Rhizophora, and Avicennia mangroves and barren area. Results show that total organic carbon (TOC) contents range between 0.34 and $3.92 \mathrm{wt} . \%$ and are higher in sediments from mudflat and Rhizophora mangrove than in sediments from Avicennia mangrove and barren area. Indeed, sediments stored under Avicennia is subjected to suboxic conditions initiated by roots system and crabs bioturbation; while under Rhizophora and mudflat, local anoxic conditions are prevalent as suggest the negative Eh values and the occurrence of framboidal pyrites. Mangrove sediments of the Somone estuary contain an autochthonous lignocellulosic-derived organic matter. The youngest and stunted form of the Somone mangrove explains the low organic carbon content of sediments; where dry climate conditions limit the organic matter production by the mangrove forest.
\end{abstract}

The shallow depth at which the organic matter of the former mudflat was found confirms that the Somone mangrove is subjected to a low sedimentation rate. This suggests that organic carbon burial depends on others processes than sedimentation. Then, in the Somone mangrove ecosystem, both of pneumatophores and burrowing crab activities are the main factors that control OM degradation (Avicennia station) while anaerobic conditions (mudflat and Rhizophora) promote OM preservation. 
Keywords : Mangrove sediments; Organic carbon; pH/redox; Bioturbation; Tide; Somone estuary

\section{Introduction}

$75 \%$ of world's tropical coasts $\left(>150,000 \mathrm{~km}^{2}\right)$ are covered by mangroves forests considered as one of the major transitional ecosystems between terrestrial and marine environments (Spalding et al., 1997). Mangroves are present throughout the West African coast, and particularly from Senegal to Sierra Leone where they cover an area of about 3 millions hectares (Marius and Lucas, 1991). Mangrove ecosystems are highly productive, rich in biodiversity and support numerous ecological functions (Chong et al., 1996, Schaffelke et al., 2005, Wolanski, 2007, Alongi, 2008, Nagelkerken et al., 2008 and Comeaux et al., 2012) and human services (Rönnbäck et al., 2007, Walters et al., 2008, Alongi, 2011 and Badola et al., 2012). Despite its importance, a reduction of surface area occupied by mangroves forests is observed worldwide, and is related as much to natural as to anthropogenic causes (Spalding et al., 1997, Ellison, 1999 and Sakho et al., 2011). However, reforestation policy was developed in order to restore and protect mangrove ecosystems (Sakho et al., 2011 and Monsef et al., 2013).

Mangroves forests are characterized by a total net primary production of $218 \pm 72 \mathrm{Tg} \mathrm{C} / \mathrm{yr}$ (Twilley et al., 1992 and Bouillon et al., 2008), making them one of the most productive natural ecosystems of the world (FAO, 2007). Due to their high productivity and transitional position, mangroves play an important role in the $\mathrm{C}, \mathrm{N}, \mathrm{P}$ biogeochemical cycles in coastal environments (Singh et al., 2005 and Kristensen et al., 2008). Hence, such environments play also a significant role in the global organic carbon budget (Chmura et al., 2003, Duarte et al., 2005 and Bouillon et al., 2008). OC in mangrove sediments can be autochthonous (mangrove detritus, litters, benthic vegetation) and/or allochthonous (coastal ecosystems vegetation, riverine transport of eroded soils, freshwater and marine phytoplankton, tidally suspended OM e.g. Goni et al., 2006, Mesnage et al., 2007, Kristensen et al., 2008 and Ranjan et al., 2011). They are both an important sink and source of OC (Twilley et al., 1992, Sanders et al., 2010, Sanders et al., 2012, Tue et al., 2011 and Donato et al., 2011). However, at global scale, particulate $\mathrm{OC}$ storage within mangrove sediments is variable as attests the wide range of TOC content measured in sediments varying between $<2.00$ and $<40.00 \mathrm{wt} . \%$, with a median particulate OC of $2.20 \mathrm{wt} . \%$ (Kristensen et al., 2008). Accordingly, improve our knowledge in the $\mathrm{OC}$ storage and $\mathrm{OM}$ dynamics in mangroves require to address to the parameters acting on these two processes in a considered mangrove ecosystem (Tue et al., 2012). Unfortunately, mangrove sediments were very seldom investigated at global scale (Marchand et al., 2008, Bouillon et al., 2008 and Sanders et al., 2010) and even more seldom at the African continent scale. Scientific investigations on African mangroves, as in Kenya (Middelburg et al., 1996) and Nigeria (Ukpong, 1995, Ukpong, 1997 and Effiong and Ayolagha, 2010) clearly were highlighted the fact that the biogeochemical characteristics of sediments - particulate and dissolved OC contents, interstitial water nutrients concentrations, redox potential, salinity are the main indicators showing that sediment biogeochemistry influences the way of mangroves development (Rhizophora, Avicennia). In Senegal, researches have mainly focused on how Saloum's and Casamance's mangrove surfaces have evolved with climate variations ( Sall, 1982, Marius, 1995 and Diop et al., 1997), but only a few and ancient studies have focused on sediment geochemistry ( Viellefon, 1969 and Marius and Lucas, 1982). The sediment colonized by the mangroves is relatively homogenous. In the mineralogical point of 
view, they are dominated by quartz and clays associated to halite, pyrite and jarosite. The clays suite is mainly composed of smectite and kaolinite ( Marius and Lucas, 1991).

In this work, we examine the bulk OM coupled with porewater chemistry in order to discuss (i) the OM sources, (ii) the OM degradation processes, (iii) the impact of bioturbation on the OM dynamics (preservation or degradation), and (iv) the impact of tidal dynamics on porewater chemistry.

\section{Materials and methods}

\subsection{Study area}

The Somone estuarine mangrove located on the Petite Côte in Senegal is a $7 \mathrm{~km}^{2}$ surface tropical ecosystem (Fig. 1A). It extends at the end of a $350 \mathrm{~m}$ length sand spit, stretches parallel to the coast (Sakho et al., 2010). This ecosystem comprises of habitats, including mangroves (Rhizophora and Avicennia), intertidal mudflats, barren area (locally named tannes), sand banks and sand spit ( Fig. 1B). The mangrove forest and the mudflats are located in the intertidal zone whereas the barren areas are in the supratidal zone ( Fig. 1C). They are submerged by exceptional tides and/or rainfall during the wet season (June to October). The mouth area ( Fig. 1B) is relatively deep (>4 m), its width varies depending on the dynamics of the distal part of the sand spit ( $7 \mathrm{~m}$ in January 2010, at the time of the study). 


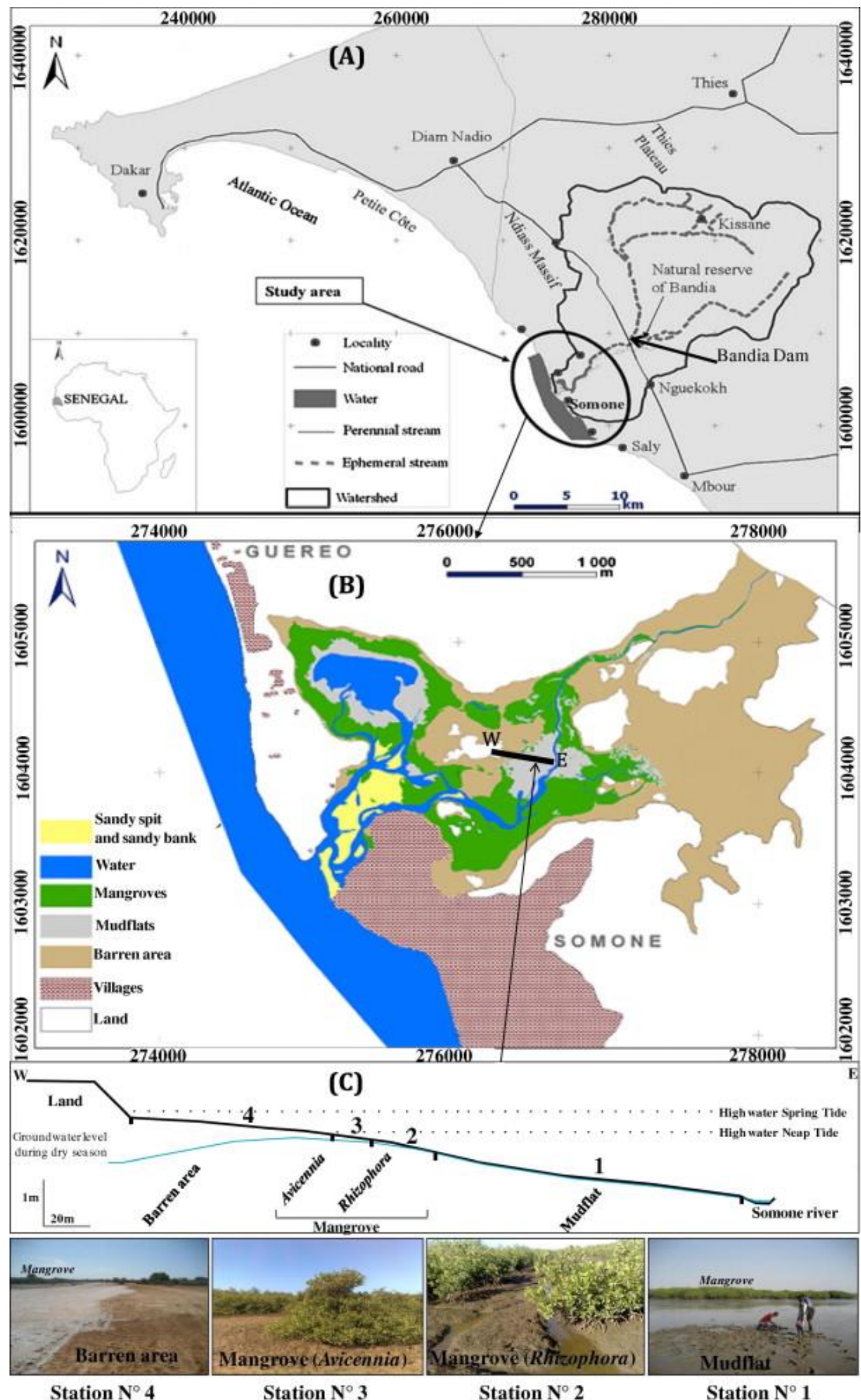

Fig. 1. : Study site localization (Somone River correspond to the Channel). 
The Somone region lies within the Atlantic Soudanian climatic zone characterized by two contrasted seasons (Leroux and Sagna, 2000). The dry season lasts approximately eight months - from November to June - and is characterized by warm and dry winds while the short rainy season lasts 3 to 4 months - from June/July to October - and is mainly ruled by monsoonal flows.

The hydrographic network of the Somone region drains a $420 \mathrm{~km}^{2}$ watershed and has little hierarchical organization. It is formed by the confluence of two ephemeral streams that meet at the Bandia reserve (Fig. 1A). Most of the flow occurs in August and September, when the maximum precipitation occurs. Since 1975 at the Bandia station, the maximum discharge has never exceeded $10 \mathrm{~m}^{3} \mathrm{~s}^{-1}$ with an annual average of $4 \mathrm{~m}^{3} \mathrm{~s}^{-1}$. The mangrove forest is located in a microtidal zone - tidal range $<2 \mathrm{~m}$ at the mouth- with a semi-diurnal tide regime. In this ecosystem, salinity is highly correlated to rainfall with rather important seasonal variations. $70 \%$ of the time, it increases when going upstream leading to a reverse estuary context. This increase in salinity from the ocean is enhanced by their location in the Northern latitude and the watershed geometry (Diop, 1990).

\subsection{Field sampling}

We have investigate a cross-section of bulk sediment along a downstream-upstream transect that respectively defines the intertidal mudflat (station 1), the Rhizophora mangrove (station 2 ), the Avicennia mangrove (station 3 ) and the barren area (station 4) corresponding to a hypersaline zone with salt efflorescence ( Fig. 1C). This transect was selected according to a salinity and a flooding-dessication gradient. Indeed, stations 1 and 2 are located in the intertidal zone and are therefore submerged at high tide. The tanne is located in the supratidal zone and is only submerged at spring tide. The Avicennia mangrove is located at the limit of these two tidal zones.

Field works were conducted during the dry season (January 2010). A set of $42 \mathrm{~cm}$-deep sediment cores was collected at the four stations with some $10 \mathrm{~cm}$-diameter PVC corers. Cores were immediately cut-off into sections from the top to the bottom $(0-2 \mathrm{~cm} / 10$ $12 \mathrm{~cm} / 20-22 \mathrm{~cm} / 40-42 \mathrm{~cm}$ ); samples were then stored at $-20{ }^{\circ} \mathrm{C}$ until their analysis.

By using a transparent pierced-PVC corer, the temperature, salinity, $\mathrm{pH}$ and redox profiles were carried out in-situ with $\mathrm{pH}-\mathrm{KCI}$-saturated glass electrode and $\mathrm{Pt} / \mathrm{Pt}-\mathrm{Ag} / \mathrm{Ag}-\mathrm{Cl}$ redox electrodes.

\subsection{Laboratory analysis}

The grain size distribution (sand to clay fractions) was performed with a micro-granulometric laser Bechman-Coulter L230.

The sediment porewater was extracted by centrifugation (3000 R/mn, during $25 \mathrm{mn})$. The concentrations in anions $\left(\mathrm{Cl}^{-}\right.$and $\left.\mathrm{SO}_{4}{ }^{2-}\right)$ and cations $\left(\mathrm{K}^{+}, \mathrm{Ca}^{2+}, \mathrm{Na}^{+}, \mathrm{Mg}^{2+}\right)$ were determined using ionic chromatography equipped with anions and cations specific columns (Metrohm IC 732, IC 733).

The dissolved organic carbon (DOC, measurement uncertainty $<5 \%$ ) was analyzed with a "TOC Shimadzu 5050" carbon analyser. 
Pyrite in sediments has been observed using Scanning electronic microscopy - Zeiss Evo40 Ep.

Sediments were air-dried at room temperature? and sieved to $<2 \mathrm{~mm}$. TOC was analyzed using the Rock-Eval 6 pyrolyser (Lafargue et al., 1998). This apparatus is now applied to quickly characterize the global geochemistry of recent OM of sediments (e.g. Disnar and Trichet, 1984 and Marchand et al., 2008), of soils (e.g. Di-Giovanni et al., 1998), or of suspended load in river (e.g. Copard et al., 2006). Between 50 and $100 \mathrm{mg}$ of dry sample are first pyrolyzed under inert atmosphere $\left(\mathrm{N}_{2}\right)$ according to a linear temperature programming $\left(25^{\circ} \mathrm{C} / \mathrm{min}\right.$ from 250 to $650{ }^{\circ} \mathrm{C}$ ). This first phase releases signals $S_{1}$ and $S_{2}$ delivered by an FID detector and corresponding respectively to the release of free hydrocarbon (already present in the sample) following by the hydrocarbon release due to the progressive OM cracking. The signal $S_{3}$ and $S_{3^{\prime}}$ that are recorded concurrently by an IR cell, come respectively from the release of $\mathrm{CO}_{2}$ and $\mathrm{CO}$ emitted during this step. The pyrolysis residue is then submitted to heating under $\mathrm{O}_{2}$ with a linear temperature programming from 300 to $750{ }^{\circ} \mathrm{C}$. An IR cell records the signals $\mathrm{S}_{4}$ and $\mathrm{S}_{4^{\prime}}$ corresponding respectively to $\mathrm{CO}_{2}$ and to $\mathrm{CO}$ produced by the combustion of the carbonaceous material.

The usual parameters of this analysis method come from the signal integration. Hydrogen Index (HI in $\mathrm{mg} \mathrm{HC/g}$ TOC), calculated from signal $\mathrm{S}_{2}$, corresponds to the hydrogen richness of the sample whereas OI RE6 (OI in $\mathrm{mg} \mathrm{O}_{2} / \mathrm{g}$ TOC) reveals the oxygenation degree of OM. Tmax (in ${ }^{\circ} \mathrm{C}$ ) corresponding to the pyrolysis temperature at which the maximum quantity of $\mathrm{HC}$ compounds are released informs on the ability for recent $\mathrm{OM}$ to be processed (i.e. hydrolysis, bacterial consummation, oxidation). RE6 pyrolysis also provides the total organic carbon content (TOC expressed in weight $\%$ ) corresponding to the sum of organic carbon (OC) calculated during the pyrolysis ( $\mathrm{PC}, \mathrm{wt} \%)$ and combustion stages (RC, wt\%). On the basis of the analyses performed with a standard from the Institut Français du Pétrole, measurements uncertainty does not exceed 3\% (Noël et al., 2001).

\section{Results}

\subsection{Grain size distribution}

Sediments in the four stations were composed of sand, silt and clay (Table 1). Considering the two first centimeters of sediment $(0-2 \mathrm{~cm})$, the mudflat (station 1$)$ is characterized by $32 \%$ of sand, $63 \%$ of silts and $5 \%$ of clay. Rhizophora (station 2) is characterized by $30 \%$ of sand, $66 \%$ of silts and $4 \%$ of clay. The sediments of Avicennia (station 3 ) were composed by $34 \%$ of sand, $63 \%$ of silts and $3 \%$ of clay whereas the barren area (station 4 ) is composed by $75.5 \%$ of sand, $23 \%$ of silts and only $1.5 \%$ of clay ( Table 1 ). Thus, at station 4 sediment grain size $(0-2 \mathrm{~cm})$ is dominated by sand fractions $(76 \%)$ whereas, the others stations $(1,2,3)$ it represents only $30 \%$ ( Table 1). This pattern in the grain size distribution is the same whatever the depth. The intertidal zones (Avicennia, Rhizophora and mudflat) are mainly dominated by silt fraction. It ranges between $59 \%$ and $79 \%$ without any vertical gradient. With the exception of a maximum value of $20 \%$ at $40-42 \mathrm{~cm}$ depth, the clay fraction ranges between $2 \%$ and $7 \%$, without any gradient with depth or the tidal stations ( Table 1). 
Table 1. Sediment grain size and porewater chemistry through a tidal cross-section.

\begin{tabular}{|c|c|c|c|c|c|}
\hline \multicolumn{2}{|l|}{ Stations } & \multicolumn{3}{|c|}{ Mangrove } & \multirow{2}{*}{$\begin{array}{c}\text { Mudflat } \\
(\%)\end{array}$} \\
\hline Parameters & Depth/units & $\begin{array}{l}\text { Barren area } \\
\text { (Tanne) }(\%)\end{array}$ & $\begin{array}{l}\text { Avicennia } \\
(\%)\end{array}$ & $\begin{array}{c}\text { Rhizophora } \\
(\%)\end{array}$ & \\
\hline \multirow{4}{*}{$63 \mu \mathrm{m}<$ Sand $<2 \mathrm{~mm}$} & $0-2 \mathrm{~cm}$ & 76 & 34 & 30 & 32 \\
\hline & $10-12$ & 69 & 26 & 27 & 21 \\
\hline & $20-22$ & 79 & 35 & 30 & 30 \\
\hline & $40-42$ & 74 & 0.3 & 30 & 30 \\
\hline \multirow{4}{*}{$2 \mu \mathrm{m}<$ Silts $<63 \mu \mathrm{m}$} & $0-2 \mathrm{~cm}$ & 22 & 63 & 66 & 63 \\
\hline & $10-12$ & 28 & 67 & 68 & 74 \\
\hline & $20-22$ & 19 & 59 & 67 & 65 \\
\hline & $40-42$ & 21 & 79.8 & 64 & 67 \\
\hline \multirow{4}{*}{ Clay $<2 \mu \mathrm{m}$} & $0-2 \mathrm{~cm}$ & 2 & 3 & 4 & 5 \\
\hline & $10-12$ & 3 & 7 & 5 & 5 \\
\hline & $20-22$ & 2 & 6 & 3 & 5 \\
\hline & $40-42$ & 5 & 19.9 & 6 & 3 \\
\hline Water content $(\%)$ & $0-10 \mathrm{~cm}$ & 17 & 27 & 55 & 49 \\
\hline Salinity $(\mathrm{g} / \mathrm{L})$ & $0-10 \mathrm{~cm}$ & $>70$ & 53 & 47 & 38 \\
\hline
\end{tabular}

The water content remains of the same order of magnitude for the first $40 \mathrm{~cm}$ of the sedimentary column. But over the cross-section, the water content of sediments shows also an increasing gradient with $17 \%, 27 \%, 55 \%$ and $49 \%$, in the tanne, Avicennia, Rhizophora and mudflat respectively ( Table 1 ).

This relative drying out can be explained by the flooding time that decreases toward the barren area (supratidal zone) to the mudflat (intertidal zone).

\subsection{Porewater physicochemical properties}

Concentrations in cations $\left(\mathrm{K}^{+}, \mathrm{Ca}^{2+}, \mathrm{Na}^{+}, \mathrm{Mg}^{2+}\right)$ measured in interstitial waters exhibit the same trend that those of anions $\left(\mathrm{Cl}^{-}\right.$and $\left.\mathrm{SO}_{4}{ }^{2-}\right)$; the concentrations are always higher in the barren area (Fig. 2A). As an example, $\mathrm{K}^{+}, \mathrm{Ca}^{2+}, \mathrm{Na}^{+}$and $\mathrm{Mg}^{2+}$ reach $0.5,0.6,12.0$ and $1.5 \mathrm{~g} / \mathrm{L}$ respectively in the mudflat while in the barren area, concentrations of these cations reach 1,1 , 22 and $2.5 \mathrm{~g} / \mathrm{L}$ respectively. This trend can also be observed for anion concentrations in interstitial waters $\left(\mathrm{Cl}^{-}\right.$and $\left.\mathrm{SO}_{4}{ }^{2-}\right)$ showing a steadily increase from the tideway toward the barren area (Fig. 2A). As an example, chloride $\left(\mathrm{C1}^{-}\right)$varies from $20.0 \mathrm{~g} / \mathrm{L}$ in the channel to $22.5 \mathrm{~g} / \mathrm{L}$ in the mudflat and to roughly $51.5 \mathrm{~g} / \mathrm{L}$ in the barren area (Fig. 2A). This hyper salinity of barren area sediments is attested by salinity values, which gradually increase from the mudflat (station 1) toward the barren area (station 4) profiles, respectively 38.0 to 
$>70.0 \mathrm{~g} / \mathrm{L}$ at sediment surface (Table. 1). $\mathrm{SO}_{4}{ }^{2-}$ varies from $3 \mathrm{~g} / \mathrm{L}$ in the mudflat to $3 \mathrm{~g} / \mathrm{L}$ in Rhizophora, $4.0 \mathrm{~g} / \mathrm{L}$ in the Avicennia and to $8.0 \mathrm{~g} / \mathrm{L}$ in the barren area.

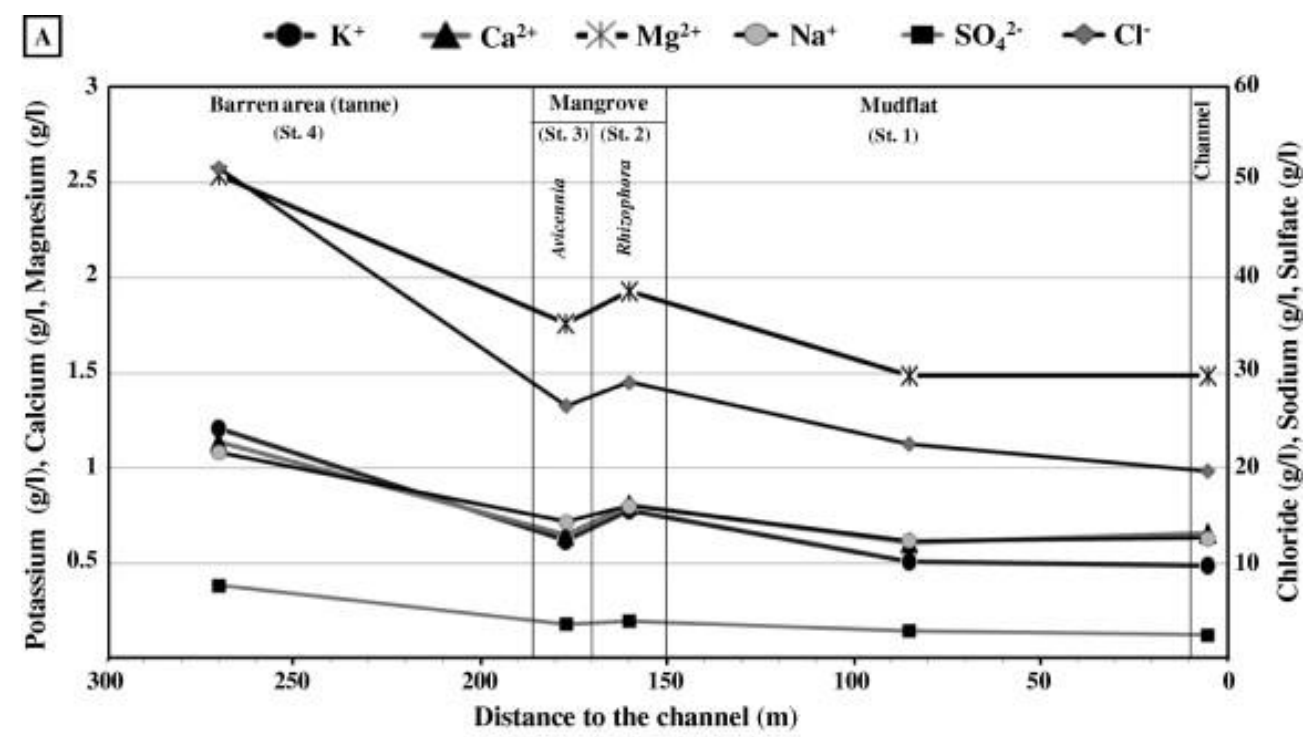

B

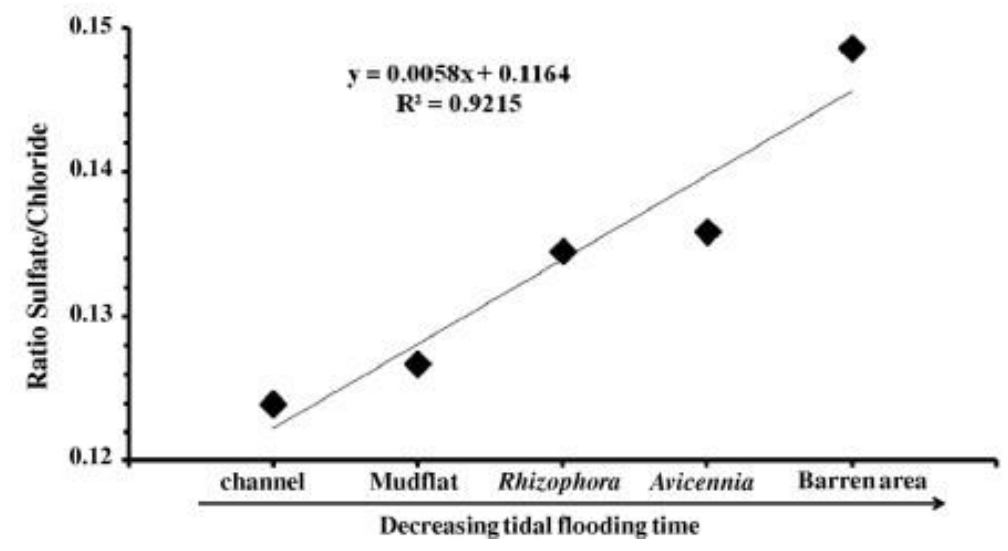

Fig. 2. : Sediment porewater chemistry (A) and ratio Sulfate/Chloride (B) variations through a tidal cross-section (st. $=$ station).

The ratio sulfate/chloride shows also the same trend. Values range from 0.12 to $0.15 \mathrm{~g} / \mathrm{L}$, respectively for the mudflat and the barren area (Fig $2 \mathrm{~B}$ ). The lower values of the $\mathrm{SO}_{4}{ }^{2-} / \mathrm{Cl}^{-}$ratio correspond to area mostly influenced by marine input. Then, these ions concentrations increasing toward the barren area are well correlated to the tidal flooding time, which decrease from the mudflat to the barren area. At station 1 (mudflat facies, Fig. 3A) temperature profile exhibits a value of $23.0{ }^{\circ} \mathrm{C}$ at the sediment surface and remains constant until $-40 \mathrm{~cm}$ depth (Fig 3A). In contrast, at station 2 (Rhizophora facies, Fig. 3A), the temperature values are not constant with depth. Indeed, at the top $2 \mathrm{~cm}$ of sediment, the temperature profile exhibit a value of $25.5^{\circ} \mathrm{C}$, then $24.0^{\circ} \mathrm{C}$ at $10 \mathrm{~cm}$ depth, then $23.0{ }^{\circ} \mathrm{C}$ at $20 \mathrm{~cm}$ depth, $24.0^{\circ} \mathrm{C}$ at $30 \mathrm{~cm}$ depth and finally $25.0^{\circ} \mathrm{C}$ at $40 \mathrm{~cm}$ depth ( Fig. 3A). At station 3 (Avicennia facies, Fig. 3A), the temperature profile is quite vertical with some temperatures reaching $22.0^{\circ} \mathrm{C} \pm 0.5^{\circ} \mathrm{C}$. At station 4 (Barren area, Fig. 3A), the temperature values are higher than the three others stations ( Fig. 3A). Temperature values range from 27.2 to $29.8^{\circ} \mathrm{C}$ all along the profile. At the 6 top $\mathrm{cm}$ of sediment, the temperatures reach values of $30.0^{\circ} \mathrm{C}$ ( Fig. $3 \mathrm{~A}$ ) then, the temperature values 
slightly decrease to to $27.0^{\circ} \mathrm{C}$ at $25 \mathrm{~cm}$ depth and remain constant until the bottom of the profile ( Fig 3A)

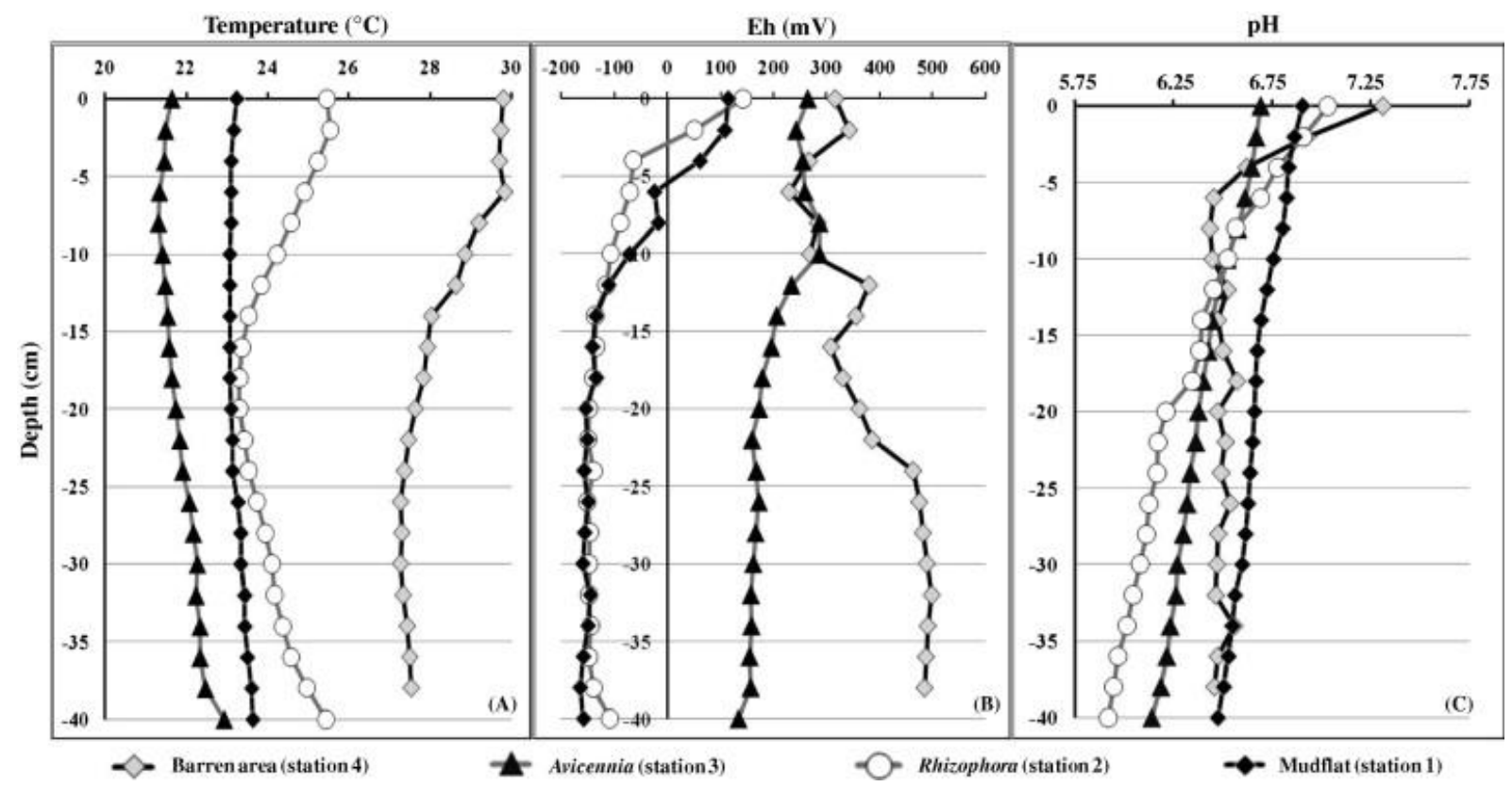

. Fig. 3.

Physico-chemical properties of sediments.

At station 1 (mudflat facies, Fig. 3B), redox profiles present some positive values, $(+100 \mathrm{mV})$ on the first $4 \mathrm{~cm}$ sediment $(0-4 \mathrm{~cm})$, the redox potential values decrease to reach $-25 \mathrm{mV}$ at $5 \mathrm{~cm}$ depth. Deeper, the redox potential values are always negative with $-70 \mathrm{mv}$ at $10 \mathrm{~cm}$ and $-150 \mathrm{mV}$ at $15 \mathrm{~cm}$ depth, and remain constant toward the bottom of the profile. At station 2 (Rhizophora facies, Fig 3B), redox potential values remain positive $(100 \mathrm{mV})$ at the top $2 \mathrm{~cm}$ of sediment, then the values become negative $(-70 \mathrm{mV})$ at $-5 \mathrm{~cm}$ depth. The Redox potential remains negative at $-10 \mathrm{~cm}(-100 \mathrm{mV})$, $-15 \mathrm{~cm}(150 \mathrm{mV})$ and until $40 \mathrm{~cm}$ depth. So, the sediment remains reduced for these two facies "mudflat" and "Rhizophora" (station 1 and 2) with the same redox potential profiles from 15 to $40 \mathrm{~cm}$ depth. These anoxic conditions in sediment at Rhizophora and mudflat stations have been pointed out by the occurrence of framboïdal pyrite ( Fig. 4). 


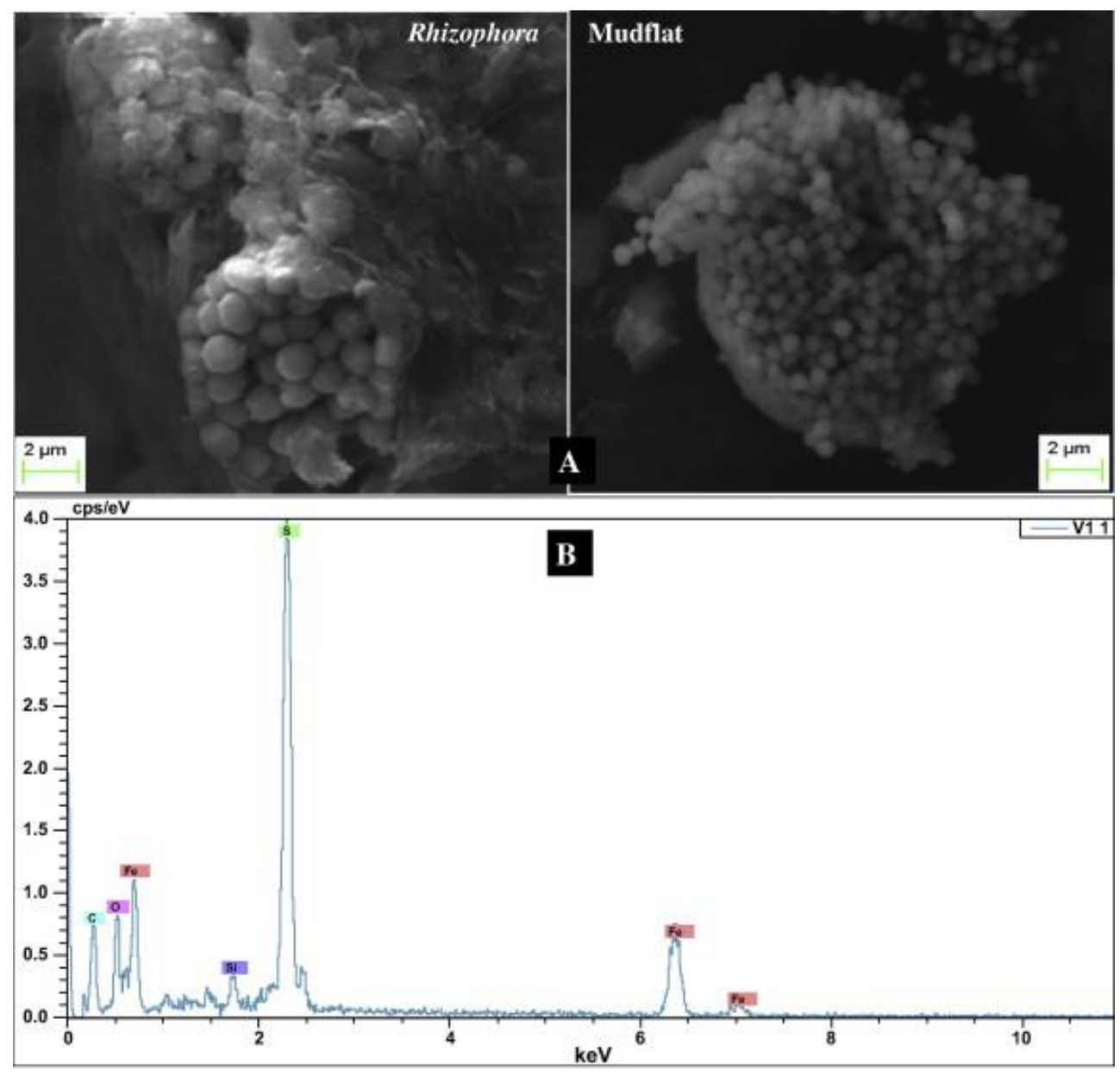

Fig. 4.

Spectrum of the pyrite in the Somone mangrove sediments (B: at the mudflat).

These pyrites are observed at $20 \mathrm{~cm}$ depth (Fig. 4). In contrast, at station 3 (Avicennia facies, Fig $3 \mathrm{~B}$ ) the redox potential profile is oxidized on the whole sedimentary column. At the sediment surface $(0-5 \mathrm{~cm})$ redox potential is $288 \mathrm{mV}$ and decreases slightly to a value of $250 \mathrm{mV}$ at $10 \mathrm{~cm}$ depth, reaches $200 \mathrm{mV}$ at $15 \mathrm{~cm}$ depth, decreases at $150 \mathrm{mV}$ at $20 \mathrm{~cm}$ depth, and remains stable deeper. At station 4 (Barren area), redox potential profile reveals also an oxidized sediment column. Indeed, redox potential values reach $300 \mathrm{mV}$ at the 2 first sediment $(0-2 \mathrm{~cm})$, then decrease at $250 \mathrm{mV}$ between 2 and $10 \mathrm{~cm}$ depth and between 15 and $40 \mathrm{~cm}$ depth, the values increase gradually from $250 \mathrm{mV}$ to $450 \mathrm{mV}$.

At station 1 (Mudflat facies - Fig 3C), sediment surface exhibit a $\mathrm{pH}$ value of 7, then the $\mathrm{pH}$ values decrease slightly all along the sediment column to reach a value of 6.75 . At station 2 (Rhizophora facies, Fig 3C), surface sediments exhibit a $\mathrm{pH}$ value of 7, then the $\mathrm{pH}$ values decrease to 6.75 at $5 \mathrm{~cm}$ depth and continue to decrease until 6.25 at $20 \mathrm{~cm}$ depth. Between 20 and $40 \mathrm{~cm}$ depth, $\mathrm{pH}$ values gradually decrease until 6 . At station 3 (Avicennia facies, Fig $3 \mathrm{C}), \mathrm{pH}$ profile varies from 6.75 at the surface sediment to $6.25 \mathrm{pH}$ unit at $40 \mathrm{~cm}$ depth, pointing out the acidic character of sediment for this facies. At station 4 (Barren area), $\mathrm{pH}$ values of top sediments $(0-5 \mathrm{~cm})$ vary from 7.25 to 6.25 , then the $\mathrm{pH}$ profile remains quite vertical with values around 6.5. The $\mathrm{pH}$ profiles of the 4 facies (stations 1, 2, 3, 4, Fig. 3C) exhibit acidic sediment all over the sedimentary column. The sediment is more acid in the first $10 \mathrm{~cm}$ depth ( $\mathrm{pH}$ from 6.4 to 7.3) whatever the facies. $\mathrm{pH}$ is more acid under Rhizophora 
(station 2) followed by Avicennia (station 3), then the Barren area (station 4) and finally the mudflat (station 1) - ( Fig. 3C).

\subsection{Particulate and dissolved organic matter of sediments}

One the whole, POC values (i.e. TOC contents) vary between 0.34 and 3.92 wt.\% (Fig. 5). In the first $11 \mathrm{~cm}$, the mudflat sediments are characterized by a TOC content around $1.50 \mathrm{wt} . \%$ increasing downward to reach $3.92 \mathrm{wt} . \%$. For Rhizophora, the TOC values vary between 1.66 and $2.14 \mathrm{wt} . \%$. TOC values for Avicennia decrease with depth $(0.56-0.34 \mathrm{wt} . \%)$ increasing to $0.63 \mathrm{wt} . \%$ at the base of the profile ( Fig. 5). With TOC values always below $0.08 \mathrm{wt} . \%$, tanne sediments are considered as devoid of organic matter. The hydrogen and oxygen richness of $\mathrm{OM}$ can respectively be expressed by the values of the hydrogen index (HI) and oxygen index (OI). In the mudflat facies, HI values rise up to $31 \mathrm{~cm}(230 \mathrm{mgHC} / \mathrm{g}$ TOC) and then decrease at the base of the profile ( $177 \mathrm{mg} \mathrm{HC} / \mathrm{g}$ TOC at $41 \mathrm{~cm}$ depth). There is an opposite trend for the evolution of OI values which drop when measuring down from the surface $\left(188 \mathrm{mg} \mathrm{O}_{2} / \mathrm{g}\right.$ TOC) up to $21 \mathrm{~cm}$ depth $(111 \mathrm{mg} \mathrm{O} / \mathrm{g}$ TOC) to then increase again at the base of the profile, $154 \mathrm{mg} \mathrm{O}_{2} / \mathrm{g}$ TOC. The recalcitrant character of recent $\mathrm{OM}$ toward further degradations can be assessed with Tmax values. Generally, this resistance to any OM processes as hydrolysis, (photo)-oxidation and biodegradation increases with increasing Tmax values ( Copard et al., 2006). Evolution of Tmax within the mudflat profile follows that of the HI values (i.e. value of $421{ }^{\circ} \mathrm{C}$ on the surface, $431{ }^{\circ} \mathrm{C}$ at $21 \mathrm{~cm}$ depth and $425^{\circ} \mathrm{C}$ at $40 \mathrm{~cm}$ depth). The measured Tmax within the profile under Rhizophora are constant between 0 and $21 \mathrm{~cm}\left(420^{\circ} \mathrm{C}\right)$ and decrease toward bottom core $\left(406^{\circ} \mathrm{C}\right)$. Between 0 and $11 \mathrm{~cm}$ depth, Tmax values under Avicennia tend to decrease from 417 to $409{ }^{\circ} \mathrm{C}$ and then remain unchanged at around $415{ }^{\circ} \mathrm{C}$ between 21 and $41 \mathrm{~cm}$.
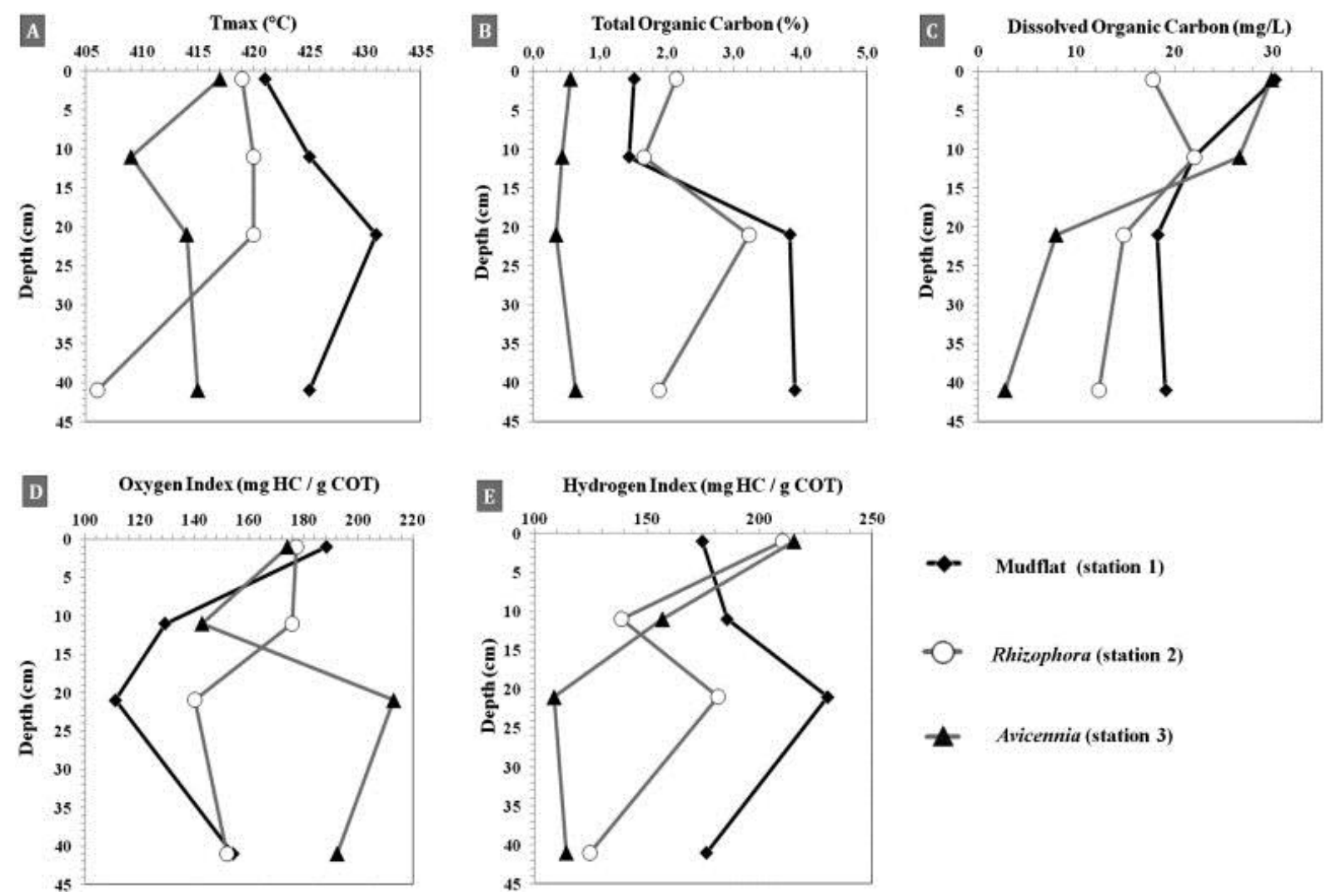

Fig. 5. : Characterization of sedimentary organic matter through Rock-Eval pyrolysis. 
Both surface sediment $(0-10 \mathrm{~cm})$ from mudflat and Avicennia profiles present a DOC concentration close to $30 \mathrm{mg} / \mathrm{L}$. Then concentrations decrease afterward with depth down to $20 \mathrm{mg} / \mathrm{l}$. For Rhizophora, the concentrations of surface sediment are lower, approximating $20 \mathrm{mg} / \mathrm{L}$. For tanne profile, DOC values are very low, always $<1 \mathrm{mg} / \mathrm{L}$ in surface sediments.

\section{Discussion}

\subsection{Sedimentary organic matter sources}

The origin of OM can be deciphered in a HI-OI Van Krevelen pseudo-diagram initially designed to characterize the origin (i.e. lacustrine, marine, terrestrial) of source rocks releasing oil and gas (Espitalié et al., 1985 and Lafargue et al., 1998). For recent OM characterization, this diagram highlights the nature of OM, from a lignocellulosic, pollen/spore origin to a lipid-rich wax or microorganisms origin (Meyers and Lallier-Verges, 1999). On the whole, OM of lignocellulosic type presents some low HI values ( $<250 \mathrm{mg} \mathrm{HC} / \mathrm{g}$ TOC) associated to high OI values ( $>100 \mathrm{mg} \mathrm{O}_{2} / \mathrm{g}$ TOC) whereas aquatic OM presents higher HI values (>400 mg HC/g TOC) associated to lower OI values ( $<100 \mathrm{mg} \mathrm{O}_{2} / \mathrm{g}$ TOC) (Marchand et al., 2008). Contrary to a previous extensive research that has shown the role of microbial or algal mats (Kristensen et al., 2008), such an influence was not observed for this study. This absence of algal mats, yet frequently observed in sediment surface of mangrove environment, can be related to the high biodegradability of this OM during early diagenesis; a very important processes in such environments (Patience et al., 1995 and Marchand et al., 2003). This limited input of aquatic OM in the sedimentary columns would be related to the very low sedimentation rates ( $2 \mathrm{~mm} / \mathrm{year})$ measured on the mudflat (Sakho et al., 2011) increasing the exposure duration of aquatic OM to the biodegradation process in surface sediments.

If $\mathrm{OM}$ has a lignocellulosic origin, it can however be at least partly allochthonous and may originate from the watershed. In such case, OM is conveyed with the suspended load by the drainage network as already observed in Kenya (Bouillon et al., 2007). However, (i) the Somone river dries out nine months out of twelve, (ii) shows a very low average annual flow of around $4 \mathrm{~m}^{3} / \mathrm{s}$ and (iii) sediment load mainly stored at the foot of Bandia dam since 1999 (Fig. 1A). In addition, over the 2007/2010 period, no hydric fluxes were observed downstream the dam. This terrestrial OM should therefore be minor, or even inexistent compared to the mangrove productivity. However, terrestrial OM could also be carried out by the sea currents coming from a river with a high sediment load and located near the study site.

This situation that prevails only when the sea currents are favorable, was already observed in mangroves of French Guinea's that accumulate strongly altered terrestrial OM originated from Amazonia's mouth (Marchand et al., 2008). Yet, this allochthonous terrestrial OM would show HI values inferior to $150 \mathrm{mg} \mathrm{HC} / \mathrm{g}$ TOC and extremely high OI, comprised between 200 and $800 \mathrm{mg} \mathrm{O}_{2} / \mathrm{g}$ TOC (Marchand et al., 2008) (Fig. 6A) but this was not observed here. Regarding all these features, sedimentary OM may probably come from a unique lignocellulosic source from the local root production (Twilley et al., 1992, Chen and Twilley, 1999 and Otero et al., 2006). This hypothesis is reinforced by the high determination coefficient $\left(R^{2}>0.90\right)$ between S2 and TOC parameters ( Fig. 6B) indicating a homogeneous OM ( Noël et al., 2001) whatever the studied profile. 

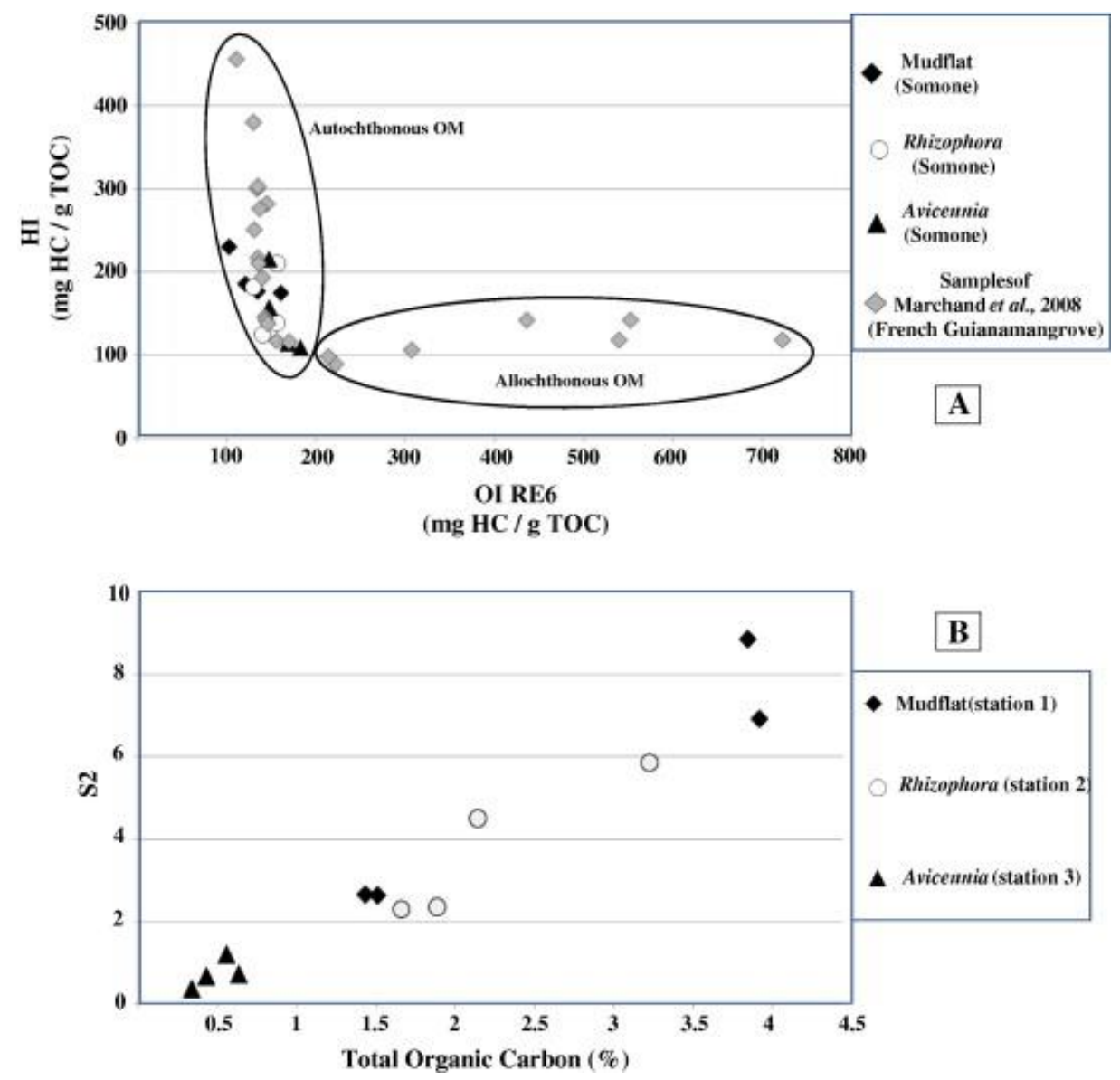

Fig. 6. : Organic matter sources in the Somone mangrove sediments.

\subsection{Sedimentary organic carbon dynamics: storage (preservation) or degradation}

Organic mater (OM) degradation in mangrove surface sediments is well described in literature as an acidification process within the sedimentary column (Marius and Lucas, 1982). This process corresponds to an intense sulfate reduction activity leading to the degradation of the $\mathrm{OM}$, which produces organic acids acidifying the sediment. The $\mathrm{pH}$ values of surface sediments, varying from 6.75 to 7.25 , are consistent with literature on the mangrove surface sediments as in Senegal, especially in the Casamance and Sine-Saloum (Marius and Lucas, 1982), in Belize (Feller et al., 2002), in French Guiana (Marchand et al., 2004) and in Tanzania (Lyimo and Mushi, 2005 and Sjöling et al., 2005).

OM processes are also controlled by redox-potential conditions in sediment. Indeed anaerobic reactions, performed by the sulfate reducing bacteria, consume the whole oxygen contained in the sediment. Via their roots, Rhizophora enhance pyrite precipitation and promote dominant reduction conditions. Pyrite formation (framboidal pyrite) occurs through the reduction of sulfates that are directly brought by seawater. Anaerobic environment preserved in the deposit from the sediment interface to $-40 \mathrm{~cm}$ depth, was already described for mangroves in the Casamance and the Saloum regions ( Marius and Lucas, 1982 and Marius, 1995), in Columbia ( Cardona and Botero, 1998), in Mexico ( Giani et al., 1996). The POC content is evaluated with the total organic carbon (TOC) values that were measured on the sediment column, ranging from 0.34 to $3.92 \mathrm{wt} . \%$ for the four profiles. All these values are low but range within the average generally accepted for mangroves sediments ( Kristensen et al., 2008). In West 
Africa, data on the storage capacity of organic carbon in sediments are scarce. Only average values of OC, from 3.60 to $9.20 \mathrm{wt} . \%$, were measured along a $40 \mathrm{~cm}$ depth on different vegetal units of Nigeria's mangrove forests ( Ukpong, 1995 and Ukpong, 1997). Other investigations at the South of Senegal (Basse Casamance, Vieillefon, 1977) have shown approximately similar values to those we obtained on the Somone's transect.

However, TOC contents of surface sediments are low compared to surface sediment sampled in some mature mangroves where TOC can frequently reach 15.00 wt.\% (Lallier-Vergès et al., 1998 and Marchand et al., 2003). Globally, sedimentary OC content increases according to mangrove ageing (Marchand et al., 2003). This can be explained by litter production that, in early development stages of the mangrove, is only sufficient to compensate the loss of OC due to OM processes at the surface sediments. Accordingly, OC storage is necessarily less important for the Somone's mangrove which can be qualified as a "young mangrove". Indeed a work on this same study site has shown that, between 1946 and 1978, 85\% of the mangrove surface disappeared to the benefit of mudflats because of concomitant effects of anthropogenic and natural factors: domestic use of mangrove woods, drought developed in 1970 and sand barrier migrated (1974) thus isolating the ecosystem and leading to a hypersaline environment. However, reforestation efforts were carried out at the beginning of the 1990s, and the area was changed into a natural reserve of common interests in 1999. Mangrove surfaces have increased with factor 5 during 15 years and have thus highlighted the capacity of vegetal recovery over a decade. This is the reason why this mangrove forest is young (two decades) with a low sedimentation rate, around $2 \mathrm{~mm} /$ year (Sakho et al., 2011). Thus, the production of autochthonous OC due to the fall of the mangrove leaves and stems occurring since two decades, justifies the small amount of TOC contained in the sediments. Moreover, in the intertidal zone, the mangrove undergoes the tide energy level; this allows part of the litter (autochthonous OM) to be exported at each tide, thus limiting the accumulation and degradation of this autochthonous OM to the same extent.

OC storage which can be seen as an OM accumulation/preservation in the sediment varies according to the studied profiles. For the mudflat profile (station 1) and Rhizophora (station 2), OC storage clearly appears $10 \mathrm{~cm}$ below the surface where TOC values increase up to $20 \mathrm{~cm}$ to then stabilize on the remaining part of the investigated sedimentary column. OM is subjected to a mineralization process and becomes much more resistant as evidenced by the abrupt drop of the $\mathrm{C}$ ratio (24.38 down to 18.40). Variability of TOC contents in this crosssection is obviously related to the grain size of sediment (i.e. fine sediment associated to higher TOC content). Nonetheless, other factors as bioturbation activity, mangrove forest age, physiological activities of the root system, the extent of water logging and intensity of faunal burrowing activities can influence the OC preservation in these coastal environment ( Kristensen et al., 2008, Perry and Berkeley, 2009, Tue et al., 2012, Donato et al., 2011, Fanjul et al., in press and Andreetta et al., 2014).

\subsection{How bioturbation contribute to $\mathrm{OM}$ dynamic?}

Bioturbation refers to the biological reworking of soils and sediments and impacts sediment texture, bio-irrigational transport of solutes and the dispersal of solid particles (Meysman et al., 2006). In mangrove coastal systems, crabs are one of the most abundant macrobenthos that affect sedimentary compartment by their activities. Field investigations in many coastal studies have shown the relationship between crabs burrowing activities and the organic carbon dynamic and sediment oxygenation processes. According to Robertson, 1986 and Twilley et al., 1997, some crabs reduce carbon export from mangrove forest by an 
important burying litter through their burrows. Same observations are noticed in many recent studies, where authors show that crab burrows activities increase zones of detritus retention and can locally increase sediment OM content by trapping detritus and OM rich sediments (Escapa et al., 2008 and Montemayor et al., 2011). More recently, Luppi et al. (2013) conclude that this pattern could particularly be important in systems characterize by low OM content, such as Mar Chiquita (3.8\%) and Bahia San Antonio (1.8\%) in SW Atlantic intertidal zones. Our results in the Somone mangrove ecosystem, which is characterized by low OC sediment content (range from 0.30 to $3.90 \mathrm{wt} \%$ ), are in contrast to these conclusions. Two sediment types characterize the Somone mangrove coastal system: bioturbated and nonbioturbated sediment, linked to our four-studied stations. The non-bioturbated sediment at mudflat and Rhizophora stations, are characterized by a higher \% OC content than the bioturbated sediment at Avicennia station, which is marked by the most higher DOC content in the first $15 \mathrm{~cm}$ sediment depth. The Barren area (stations 4) is a bioturbated zone but without any sedimentary OM, due to lack of vegetation and mangrove detritus retention. This result is in accordance to those of Otani et al. (2010), which give a burrow depth ranges from 3.3 to $16.5 \mathrm{~cm}$. However, ours results is in accordance with those recently published ( Fanjul et al., in press and Andreetta et al., 2014) showing the highest OC contents in non-bioturbated superficial sediment than in bioturbated sediment. Results of Wilson et al. (2012) indicate also the same conclusions: crab borrowing activity increase oxidized conditions in the upper of $10-15 \mathrm{~cm}$ of the sediment, which significantly lead to OM degradation. Thus, these results suggest that crab bioturbation increases sediment permeability, water percolation, and subsequently increases aerobic condition, which caused mineralization of sedimentary OM.

This explains the fact that, DOC is higher in Avicennia than in Rhizophora or mudflat. According to Benner et al. (1991), substantial quantities of DOC are produced during OM decomposition; which increase with aerobic condition. Koo et al., 2005, Xin et al., 2009 and Thomas and Blum, 2010 have shown that burrows structures of crab increase oxygen exchanges from both the atmosphere and tidal waters. This pattern is observed in the Avicennia station (bioturbated sediment), which is characterized by a most positive Eh at the first $15 \mathrm{~cm}$ depth (between +200 and $+300 \mathrm{mV}$ ). However, a second factor that participates in sediment oxidation is linked to the physiology of the Avicennia species that introduces oxygen along a 15-20 cm depth via their specific roots system (pneumatophores) and thus maintaining suboxic conditions ( Thibodeau and Nickerson, 1986, Marchand et al., 2003 and Otero et al., 2006). The roots network activity on the first half of the profile clearly explains the drop in TOC and HI values while OI values increase. This oxidizing environment increases the DOC concentration at sediment surface $(30 \mathrm{mg} / \mathrm{L})$; such a process has already been observed for mangrove forests in French Guyana ( Marchand et al., 2004).

Nonetheless, the context of non-bioturbated sediment and the dominated anoxic conditions at the mudflat and Rhizophora station, attested by negative Eh value from $5 \mathrm{~cm}$ depth and the framboïdal pyrite occurrence, are favorable conditions to OM storage processes and lead to protect it from further OM processes and in such cases, TOC values can exceed $3.00 \mathrm{wt} . \%$. The shallow depth at which such old organic matter was found ( Sakho et al., 2011) confirms that the Somone mangrove is characterized by a low sedimentation rate. This suggests that OC burial depends on others processes than sedimentation. Then, in the Somone mangrove ecosystem, both of pneumatophores and crab burrowing activities are the main factors that control OM degradation (Avicennia station) whereas anaerobic conditions (mudflat and Rhizophora) promote OM preservation. 


\subsection{Impact of tidal dynamic on porewater chemistry}

A salinity gradient is well marked, with the formation of salt efflorescence on the tanne facies (supratidal zone), as a consequence of the over-concentration in chlorides and sulfates. Indeed at high tide, the mudflat and mangrove Rhizophora in the intertidal zone are recovered by seawater that provides concentration of chloride and sulfate ions close to those of the seawater. On the contrary, the tanne facies located in the supratidal zone is only submerged during the strongest high tides. High temperatures and absence of vegetation involve a severe evaporation of seawater explaining high concentrations in chlorides and sulfates. In hot and dry climatic contexts as in Sahel, processes of over-concentration have been described in literature on other Senegalese estuaries (Viellefon, 1969 and Marius, 1995) but also in Mexico ( Day et al., 1996), in Australia ( Ridd and Stieglitz, 2002). Impact of the deficient in the annual hydrologic budget has also been pointed out, associated with a shallow groundwater, the phenomenon of salt concentrate through capillary-driven can well explain salt efflorescence characterizing the ascending saline profile ( Bouteyre and Loyer, 1992).

Other authors have demonstrated a clear tidal signature with water column nutrients concentration (DOC, phosphate and nitrogen) covaried with salinity controlling the sediment porewater chemistry (Lara and Dittmar, 1999 and Dittmar and Lara, 2001). Otherwise, at the sediment surface, the impact of tidal dynamic can be deciphered with $\mathrm{pH}$ values fluctuation. The regular input of seawater of basic $\mathrm{pH}(\mathrm{pH}>8)$ on the mudflat and mangrove Rhizophora facies explains the less acid $\mathrm{pH}$ values as for the Avicennia facies. However, sediment acidification can result from OM decomposition, but also from sulfur oxidation ( Marchand et al., 2003). Mangrove sediments are subjected to an alternation of oxic and anoxic decay processes, which can lead to a production of sulfur and then to their dissolution. Our results show that the biogeochemistry of mangrove sediments is strongly influenced by local environmental conditions (tidal flooding, duration of inundation, without freshwater input, seasonality of precipitation and temperature, bioturbation, etc.). These findings were evidenced in other mangroves area (Luther et al., 1991 and Attri et al., 2011).

\section{Conclusion}

Organic geochemical signature of sediments suggests that sedimentary OM is mainly lignocellulosic-derived. Absence of algal mat is linked to the low sedimentation rate increasing the duration exposure of this OM to the biodegradation process. The low TOC content in sediments, reflect the low organic matter production of the mangrove as it is a young and stunted mangrove. Youth of mangrove, coupled to the low sedimentation rate and the drastic conditions (i.e. drought, absence of fluvial freshwater input, high evaporation rate, hypersalinisation) and bioturbation are the main limiting factors preventing the sedimentary OC preservation in this mangrove sediments. Our result show that the redox conditions in mangrove ecosystem depend mainly to the mangrove genus e.g. the physiology of Avicennia permits the introduction of oxygen via their pneumatophores, maintaining suboxic conditions. In the first $15 \mathrm{~cm}$ of the sedimentary column, such conditions are also enhanced by the burrowing crabs activities, which cause OM degradation. The tidal flooding time, which decrease toward the barren area (supratidal zone) to the mudfltat (intertidal zone) is the main factor that control the drying out and the porewater chemistry of the sedimentary facies along this intertidal-supratidal cross-section.

The shallow depth at which the organic matter of the former mudflat was found confirms that the Somone mangrove is characterized by a low sedimentation rate. This suggests that OC 
burial depends on others processes than sedimentation. Then, in the Somone mangrove ecosystem, both of pneumatophores and crab burrowing activities are the main factors that control OM degradation (Avicennia station) whereas anaerobic conditions (mudflat and Rhizophora) aim to OM preservation.

\section{Acknowledgements}

This work is a contribution to the "HySo Project", an international collaboration between Universities of Rouen (France) and Dakar (Senegal). One of author is supported by CNRS grant (Bourse Doctorat-Ingénieur). The authors give many thanks to Marie Gspann for English translation and Dr. David Sebag for the comments. The authors would like to thank two anonymous reviewers for their very useful criticism and suggestions for improvement. We would also like to thank: Souleymane Sakho, Abdoulaye Sakho, Mbaye bis, Ousmane Diao and Touré dit Zizou, for their assistance in the field.

\section{References}

Alongi, 2011

D.M. Alongi

Carbon payments for mangrove conservation: ecosystem constraints and uncertainties of sequestration potential

Environ. Sci. Pol., 14 (2011), pp. 462-470

Alongi, 2008

D.M. Alongi

Mangrove forests: resilience, protection from tsunamis, and responses to global climate change

Estuar. Coast. Shelf Sci., 76 (2008), pp. 1-13

Andreetta et al., 2014

A. Andreetta, M. Fusi, I. Cameldi, F. Cimo, S. Carnicelli, S. Cannicci

Mangrove carbon sink. Do burrowing crabs contribute to sediment carbon storage?

Evidence from a Kenyan mangrove system

J. Sea Res., 85 (2014), pp. 524-533

Attri et al., 2011

K. Attri, S. Kerkar, P.A. Loka Bharathi

Ambient iron concentration regulates the sulfate reducing activity in the mangrove swamps of Diwar, Goa, India

Estuar. Coast. Shelf Sci., 95 (2011), pp. 156-164

Badola et al., 2012

R. Badola, S. Barthwal, S.A. Hussain

Attitudes of local communities towards conservation of mangrove forests: a case study from the east coast of India

Estuar. Coast. Shelf Sci., 96 (2012), pp. 188-196

Benner et al., 1991

R. Benner, M.L. Fogel, E.K. Sprague

Diagenesis of belowground biomass of Spartina alterniflora in salt-marsh sediments 
Limnol. Oceanogr., 36 (1991), pp. 1358-1374

Bouillon et al., 2008

S. Bouillon, A.V. Borges, E. Castaneda-Moya, K. Diele, T. Dittmar, N.C. Duke, E. Kristensen, S.Y. Lee, C. Marchand, J.J. Middelburg, V.H. Rivera-Monroy, T.J. Smith III, R.R. Twilley

Mangrove production and carbon sinks: a revision of global budget estimates

Global Biogeochem. Cycles, 22 (2008), pp. 1-12

Bouillon et al., 2007

S. Bouillon, F. Dehairs, L.S. Schiettecatte, A.V. Borges

Biogeochemistry of the Tana estuary and delta (northern Kenya)

Limnol. Oceanogr., 52 (2007), pp. 46-59

Bouteyre and Loyer, 1992

Bouteyre, G., Loyer, J.Y., 1992. Sols salés, eaux saumâtres, des régions arides tropicales et méditerranéennes: principaux faciès, conséquences pour l'agriculture. In: Le Floc'h, E., Grouzis, M., Cornet, A., Bille, J.C., L'aridité: une contrainte au développement. Edition de I'ORSTOM, Paris, pp. 69-80.

Cardona and Botero, 1998

P. Cardona, L. Botero

Soil characteristics and vegetation structure in a heavily deteriorated Mangrove forest in the Caribbean coast of Colombia

Biotropica, 30 (1) (1998), pp. 24-34

Chen and Twilley, 1999

R. Chen, R.R. Twilley

A simulation model of organic matter and nutrient accumulation in mangrove wetlands soils

Biogeochemistry, 44 (1999), pp. 93-118

Chmura et al., 2003

G.L. Chmura, S.C. Anisfeld, D.R. Cahoon, J.C. Lynch

Global carbon sequestration in tidal, saline wetland soils

Global Biogeochem. Cycles, 17 (2003), p. 1e12

Chong et al., 1996

V.C. Chong, A. Sasekumar, E. Wolanski

The role of mangroves in retaining penaeid prawn larvae in Klang Strait, Malaysia Mangroves Salt Marshes, 1 (1) (1996), pp. 11-22

Comeaux et al., 2012

R.S. Comeaux, M.A. Allison, T.S. Bianchi

Mangrove expansion in the Gulf of Mexico with climate change: implications for wetland health and resistance to rising sea levels

Estuar. Coast. Shelf Sci., 96 (2012), pp. 81-95

Copard et al., 2006

Y. Copard, Ch. Di-Giovanni, T. Martaud, P. Albéric, J.E. Ollivier 
Using Rock-Eval 6 pyrolysis for tracking fossil organic carbon in modern environments: implications for the roles of erosion and weathering

Earth Surf. Proc. Land., 31 (2006), pp. 135-153

Day et al., 1996

J.W. Day Jr., C. Coronado-Molina, F.R. Vera-Herrera, R. Twilley, V.H. Rivera-Monroy, H. Alvarez-Guillen, R. Day, W. Conner

A 7-year record of above-ground net primary production in a southeastern Mexican mangrove forest

Aquat. Bot., 55 (1996), pp. 39-60

Di-Giovanni et al., 1998

C. Di-Giovanni, J.R. Disnar, V. Bichet, M. Campy, B. Guillet

Geochemichal characterization of soil organic matter and variability of a past

glacial detrital organic supply (Chaillexon Lake, France)

Earth Surf. Proc. Land., 23 (1998), pp. 1057-1069 (pour les sédiments)

Disnar and Trichet, 1984

J.R. Disnar, J. Trichet

The influence of various divalent cations $\left(\mathrm{UO}^{2+}, \mathrm{Cu}^{2+}, \mathrm{Pb}^{2+}, \mathrm{Co}^{2+}, \mathrm{Ni}^{2+}, \mathrm{Zn}^{2+}\right.$, $\mathrm{Mn}^{2+}$ ) on thermally induced evolution of organic matter isolated from an algal mat Org. Geochem., 6 (1984), pp. 865-874

Diop et al., 1997

E.S. Diop, A. Soumaré, N. Diallo, A. Guissé

Recent changes of the mangroves of the Saloum River Estuary, Senegal

Mangrove Salt Marshes, 1 (1997), pp. 163-172

Diop, 1990

Diop, E.S., 1990. La côte ouest africaine du Saloum (Sénégal) à la Mellacorée (République de Guinée). Collection Etudes et Thèses, éditions de l'ORSTOM, Paris, 381p.

Dittmar and Lara, 2001

T. Dittmar, R.J. Lara

Driving forces behind nutrient and organic matter dynamics in a mangrove tidal creek in North Brazil

Estuar. Coast. Shelf Sci., 52 (2001), pp. 249-259

Donato et al., 2011

D.C. Donato, J.B. Kauffman, D. Murdiyarso, S. Kurnianto, M. Stidham, M. Kanninen

Mangroves among the most carbon-rich forests in the tropics

Nat. Geosci., 4 (2011), pp. 293-297

Duarte et al., 2005

C.M. Duarte, J.J. Middelburg, N. Caraco

Major role of marine vegetation on the oceanic carbon cycle

Biogeosciences, 2 (2005), pp. 1-8

Effiong and Ayolagha, 2010

G.S. Effiong, G.A. Ayolagha 
Characteristics, constraints and management of mangrove soils for sustainable crop production

Electr. J. Environ. Agri. Food Chem., 9 (6) (2010), pp. 977-990

Ellison, 1999

J. Ellison

Impacts of sediment burial on mangroves

Mar. Pollut. Bull., 37 (8-12) (1999), pp. 420-426

Escapa et al., 2008

M. Escapa, G.M.E. Perillo, O. Iribarne

Sediment dynamics modulated by burrowing crab activities in contrasting SW

Atlantic intertidal habitats

Estuar. Coast. Shelf Sci., 80 (2008), pp. 365-373

Espitalié et al., 1985

Espitalié, J., Deroo, G., Marquis, F., 1985. La pyrolyse Rock-Eval et ses applications. Revue. Institut Français du Pétrole 40, 5, 563-579, 40, 6, 755-784, 41, 1, 73-89.

Fanjul et al., in press

Fanjul, E., Escapa, M., Montemayor, D., Addino, M., Fernanda, M., Alvarez, M.F., Grela, M.A., Iribarne, O., 2014. Effect of crab bioturbation on organic matter processing in South West Atlantic intertidal sediments. J. Sea Res (in press),

http://dx.doi.org.biblioplanets.gate.inist.fr/10.1016/j.seares.2014.05.005

FAO., 2007

FAO, 2007. The World's Mangroves 1980-2005. FAO Forestry, Paper 153, Rome, 2007, $89 \mathrm{p}$.

Feller et al., 2002

I.C. Feller, K.L. McKee, D.F. Whigham, J.P. O'Neill

Nitrogen vs. phosphorus limitation across an ecotonal gradient in a mangrove

forest

Biogeochemistry, 62 (2002), pp. 145-175

Giani et al., 1996

L. Giani, Y. Bashan, G. Holguin, A. Strangmann

Characteristics and methanogenesis of the Balandra lagoon mangrove soils Baja

California Suv, Mexico

Geoderma, 72 (1996), pp. 149-160

Goni et al., 2006

M.A. Goni, N. Monacci, R. Gisewhite, A. Ogston, J. Crockett, C. Nittrouer

Distribution and sources of particulate organic matter in the water column and sediments of the Fly River Delta, Gulf of Papua (Papua New Guinea)

Estuar. Coast. Shelf Sci., 69 (2006), pp. 225-245

Koo et al., 2005 
B.J. Koo, K.K. Kwon, J. Hyun

The sediment-water interface increment due to the complex burrows of macrofauna in a tidal flat

Ocean Sci. J., 40 (2005), pp. 221-227

Kristensen et al., 2008

E. Kristensen, S. Bouillon, T. Dittmar, C. Marchand

Organic carbon dynamics in mangrove ecosystems: a review

Aquat. Bot., 89 (2008), pp. 201-219

Lafargue et al., 1998

E. Lafargue, F. Marquis, D. Pillot

Rock-Eval 6 applications in hydrocarbon exploration, production, and soil contamination studies

Rev. Inst. Fr. Pétrol., 53 (4) (1998), pp. 421-437

Lallier-Vergès et al., 1998

E. Lallier-Vergès, B.P. Perrussel, J.R. Disnar, F. Baltzer

The relationship between environmental conditions and the diagenetic evolution of organic matter derived from higher plant in a present mangrove swamp system

(Guadeloupe, French West Indies)

Org. Geochem., 29 (1998), pp. 1663-1686

Lara and Dittmar, 1999

R.J. Lara, T. Dittmar

Nutrient dynamics in mangrove creek (North Brazil) during the dry season

Mangroves Salt Marshes, 3 (1999), pp. 185-195

Leroux and Sagna, 2000

Leroux, M., Sagna, P., 2000. Le climat. In: Atlas du Sénégal. Ed. Jeune Afrique, pp. 16-19.

Luther et al., 1991

G.W. Luther, T.G. Ferdelman, J.E. Kostka, E.J. Tsamakis, T.M. Church

Temporal and spatial variability of reduced sulfur species (pyrite, thiosulfate) and pore water parameters in salt marsh sediment

Biogeochemistry, 14 (1991), pp. 57-88

Luppi et al., 2013

T. Luppi, C. Bas, A. Méndez Casariego, M. Albano, J. Lancia, M. Kittlein, A. Rosenthal, N. Farías, E. Spivak, O. Iribarne

The influence of habitat, season and tidal re- gime in the activity of the intertidal crab Neohelice (=Chasmagnathus) granulata

Helgol. Mar. Res., 67 (2013), pp. 1-15

Lyimo and Mushi, 2005

T.J. Lyimo, D. Mushi

Sulfide concentration and redox potential patterns in mangrove forests of Dar es

Salaam: Effects on Avicennia marina and Rhizophora mucronata seedling

establishment

West. Indian Ocean J. Mar. Sci., 4 (2) (2005), pp. 163-173 
Marchand et al., 2008

C. Marchand, E. Lallier-Vergèsa, J.R. Disnara, D. Kéravisa

Organic carbon sources and transformations in mangrove sediments: a Rock-Eval pyrolysis approach

Org. Geochem., 39 (2008), pp. 408-421

Marchand et al., 2004

C. Marchand, F. Baltzer, E. Lallier-Vergès, P. Albéric

Pore-water chemistry in mangrove sediments: relationship with species

composition and developmental stages (French Guiana)

Mar. Geol., 208 (2004), pp. 361-381

Marchand et al., 2003

C. Marchand, E. Lallier-Vergès, F. Baltzer

The composition of sedimentary organic matter in relation to the dynamic features of a mangrove-fringed coast in French Guiana

Estuar. Coast. Shelf Sci., 56 (2003), pp. 119-130

Marius and Lucas, 1991

C. Marius, J. Lucas

Holocene mangrove swamps of West Africa sedimentology and soils

J. Afr. Earth Sci., 12 (1991), pp. 41-54

Marius, 1995

C. Marius

Effets de la sécheresse sur l'évolution des mangroves du Sénégal et de la Gambie

Sécheresse, 6 (1) (1995), pp. 123-126

Marius and Lucas, 1982

Marius, C., Lucas, J., 1982. Evolution géochimique et exemple d'aménagement des mangroves au Sénégal (Casamance). In: Oceanologica Acta. Les lagunes côtières:

Symposium International, Bordeaux, pp. 151-160.

Mesnage et al., 2007

V. Mesnage, S. Ogier, G. Bally, J.-R. Disnar, N. Lottier, K. Dedieu, C. Rabouille, Y. Copard Nutrient dynamics at the sediment-water interface in a Mediterranean lagoon (Thau, France): influence of biodeposition by shellfish farming activities

Mar. Environ. Res., 63 (2007), pp. 257-277

Meyers and Lallier-Verges, 1999

P. Meyers, E. Lallier-Verges

Lacustrine sedimentary organic matter records of Late Quaternary paleoclimates

J. Paleolimnol., 21 (1999), pp. 345-372

Meysman et al., 2006

F.J.R. Meysman, J.J. Middelburg, C.H.R. Heip

Bioturbation: a fresh look at Darwin's last idea

Trends Ecol. Evol., 21 (12) (2006), pp. 688-695

Middelburg et al., 1996

J.J. Middelburg, J. Nieuwenhuize, F.J. Slim, B. Ohowa 
Sediment biogeochemistry in an East African mangrove forest (Gazi Bay, Kenya) Biogeochemistry, 34 (1996), pp. 133-155

Monsef et al., 2013

H.A. Monsef, A.S.H. Aguib, S.E. Smith

Locating suitable mangrove plantation sites along the Saudi Arabia Red Sea Coast J. Afr. Earth Sci., 83 (2013), pp. 1-9

Montemayor et al., 2011

D.I. Montemayor, M. Addino, E. Fanjul, M. Escapa, M.F. Alvarez, F. Botto, O.O. Iribarne Effect of dominant Spartina species on salt marsh detritus production in SW Atlantic estuaries

J. Sea Res., 66 (2011), pp. 104-110

Nagelkerken et al., 2008

I. Nagelkerken, S.J.M. Blaber, S. Bouillon, P. Green, M. Haywood, L.G. Kirton, J.O.

Meynecke, J. Pawlik, H.M. Penrose, A. Sasekumar, P.J. Somerfield

The habitat function of mangroves for terrestrial and marine fauna: a review

Aquat. Bot., 89 (2) (2008), pp. 155-185

Noël et al., 2001

H. Noël, E. Garbolino, A. Brauer, E. Lallier-Verges, J.L. De Beaulieu, J.R. Disnar

Human impact and soil erosion since ca. 5000 years attested by the study of the sedimentary organic content, "Lac d'Annecy, The French Alpes"

J. Paleolimnol., 25 (2) (2001), pp. 229-244

Otani et al., 2010

S. Otani, Y. Kozuki, R. Yamanaka, H. Sasaoka, T. Ishiyama, Y. Okitsu, H. Sakai, Y. Fujiki The role of crabs (Macrophthalmus japonicus) burrows on organic carbon cycle in estuarine tidal flat, Japan

Estuar. Coast. Shelf Sci., 86 (2010), pp. 434-440

Otero et al., 2006

X.L. Otero, T.O. Ferreira, P. Vidal-Torrado, F. Macias

Spatial variation in pore water geochemistry in a mangrove system (Pai Matos

Island, Cananeia-Brazil)

Geochemistry, 21 (2006), pp. 2171-2186

Patience et al., 1995

A.J. Patience, E. Lallier-Verges, A. Sifeddine, P. Albéric, B. Guillet

Organic fluxes and early diagenesis in the lacustrine environment

E. Lallier-Verges, N. Tribovillard, P. Bertrand (Eds.), Organic Matter

Accumulation: The Organic Cyclicities of the Kimmeridge Clay Formation

(Yorkshire, G.B.) and the Recent Maar Sediments (Lac du bouchet). Lecture Notes

in Earth Sciences, vol. 57Springer Verlag, Heidelberg (1995), pp. 145-156

Perry and Berkeley, 2009

C.T. Perry, A. Berkeley

Intertidal substratemodification as a result ofmangrove planting: impacts of introduced mangrove species on sediment microfacies characteristics

Estuar. Coast. Shelf Sci., 81 (2009), pp. 225-237 
Ranjan et al., 2011

R.K. Ranjan, J. Routh, A.L. Ramanathan

Bulk organic matter characteristics in the Pichavaram mangrove - estuarine complex, south-eastern India

Appl. Geochem., 25 (2011), pp. 1176-1186

Ridd and Stieglitz, 2002

P.V. Ridd, T. Stieglitz

Dry season salinity changes in arid estuaries fringed by mangroves and saltflats

Estuar. Coast. Shelf Sci., 54 (2002), pp. 1039-1049

Robertson, 1986

A.I. Robertson

Leaf-burying crabs: their influence on energy flow and export from mixed mangrove forests (Rhizophora spp.) in northeastern Australia

J. Exp. Mar. Biol. Ecol., 116 (1986), pp. 235-247

Rönnbäck et al., 2007

P. Rönnbäck, B. Crona, L. Ingwall

The return of ecosystem goods and services in replanted mangrove forests:

perspectives from local communities in Gazi Bay, Kenya

Environ. Conserv., 34 (2007), pp. 313-324

Sakho et al., 2011

I. Sakho, V. Mesnage, J. Deloffre, R. Lafite, I. Niang, G. Faye

The influence of natural and anthropogenic factors on mangrove dynamics over 60 years: the Somone estuary, Senegal

Estuar. Coast. Shelf Sci., 94 (2011), pp. 93-101

Sakho et al., 2010

I. Sakho, V. Mesnage, J. Deloffre, R. Lafite, I. Niang, G. Faye

Rôle des forçages climatiques et anthropiques sur l'évolution des écosystèmes tropicaux de mangrove: exemple de la Somone, Sénégal

Pangea, 47 (48) (2010), pp. 69-75

Sall, 1982

Sall, M.M., 1982. Dynamique et morphogenèse actuelle au Sénégal occidental. Thèse de Doctorat d'Etat, Université Louis Pasteur de Strasbourg, 604p.

Sanders et al., 2012

C.J. Sanders, J.M. Smoak, M.N. Waters, L.M. Sanders, N. Brandini, S.R. Patchineelam

Organic matter content and particle size modifications in mangrove sediments as responses to sea level rise

Mar. Environ. Res., 77 (2012), pp. 150-155

Sanders et al., 2010

C.J. Sanders, J.M. Smoak, A.S. Naidu, L.M. Sanders, S.R. Patchineelam

Organic carbon burial in a mangrove forest, margin and intertidal mud flat

Estuar. Coast. Shelf Sci., 90 (2010), pp. 168-172 
Schaffelke et al., 2005

B. Schaffelke, J. Mellors, N.C. Duke

Water quality in the Great Barrier Reef region: responses of mangrove, seagrass and macroalgal communities

Mar. Pollut. Bull., 51 (1-4) (2005), pp. 279-296

Singh et al., 2005

G. Singh, A.L. Ramanathan, M.B.K. Prasad

Nutrient cycling in mangrove ecosystem: a brief overview

Int. J Ecol. Environ. Sci., 30 (2005), pp. 231-244

Sjöling et al., 2005

S. Sjöling, S.M. Mohammed, T.J. Lyimo, J.J. Kyaruzi

Benthic bacterial diversity and nutrient processes in mangroves: impact of deforestation

Estuar. Coast. Shelf Sci., 63 (2005), pp. 397-406

Spalding et al., 1997

Spalding, M.D., Blasco, F., Field, C.D., 1997. World Mangrove Atlas. International Society for Mangrove Ecosystems, Okinawa, Japan, 178p.

Thibodeau and Nickerson, 1986

F.R. Thibodeau, N.H. Nickerson

Differential oxidation of mangrove substrate by Avicennia germinans and

Rhizophora mangle

Am. J. Bot., 73 (1986), pp. 512-516

Thomas and Blum, 2010

C.R. Thomas, L.K. Blum

Importance of the fiddler crab Uca pugnax to salt-marsh soil organic matter accumulation

Mar. Ecol. Prog. Ser., 414 (2010), pp. 167-177

Tue et al., 2012

N.T. Tue, N.T. Ngoc, T.D. Quy, H. Hamaoka, M.T. Nhuan, K. Omori

A cross-system analysis of sedimentary organic carbon in the mangrove ecosystems of Xuan Thuy National Park, Vietnam

J. Sea Res., 67 (2012), pp. 69-76

Tue et al., 2011

N.T. Tue, H. Hamaoka, A. Sogabe, T.D. Quy, M.T. Nhuan, K. Omori

Sources of sedimentary organic carbon in mangrove ecosystems from Ba Lat

Estuary, Red River, Vietnam

K. Omori (Ed.), et al., Modeling and Analysis of Marine Environmental Problems, Terrapub, Tokyo (2011), pp. 151-157

Twilley et al., 1997

R.R. Twilley, M. Pozo, V.H. Garcia, V.H. Rivera-Monroy, R.Z.A. Bodero

Litter dynamics in riverine mangrove forests in the Guayas River estuary, Ecuador 
Oecologia, 111 (1997), pp. 109-122

Twilley et al., 1992

R.R. Twilley, R.H. Chen, T. Hargis

Carbon sinks in mangrove forests and their implications to the carbon budget of tropical coastal ecosystems

Water Air Soil Pollut., 64 (1992), pp. 265-288

Ukpong, 1997

I.E. Ukpong

Vegetation and its relation to soil nutrient and salinity in the Calabar mangrove swamp, Nigeria

Mangroves Salt Marshes, 1 (1997), pp. 211-218

Ukpong, 1995

I.E. Ukpong

Mangrove soils of the Creek town, Creek/Calabar river, South eastern Nigeria

Trop. Ecol., 36 (1995), pp. 103-115

Vieillefon, 1977

Vieillefon, J., 1977. Les Sols des Mangroves et des Tannes de Basse Casamance (Sénégal): Importance du Comportement Géochimique du Soufre dans leur Pédogénèse. ORSTOM

Paris, vol. 83, 291p.

Viellefon, 1969

Vieillefon, J., 1969. La pédogénèse dans les mangroves tropicales. Un exemple de chronoséquence. In: Sciences du Sol, Supl. Au Bull. Ass. Fr. Et. du Sol, ORSTOM, pp. 114149 .

Walters et al., 2008

B.B. Walters, P. Rönnbäck, J.M. Kovacs, B. Crona, S.A. Hussain, R. Badola, J.H. Primavera, E. Barbier, F. Dahdouh-Guebas

Ethnobiology, socio-economics and management of mangrove forests: a review Aquat. Bot., 89 (2) (2008), pp. 220-236

Wilson et al., 2012

C.A. Wilson, Z.J. Hughes, D.M. FitzGerald

The effects of crab bioturbation on mid-Atlantic saltmarsh tidal creek extension: geotechnical and geochemical changes

Estuar. Coast. Shelf Sci., 106 (2012), pp. 33-44

Wolanski, 2007

E. Wolanski

Estuarine Ecohydrology

Elsevier, Amsterdam (2007) 157 p

Xin et al., 2009

P. Xin, J. Guanggiu, Li. Ling, D.A. Barry

Effects of crab burrows on pore water flows in saltmarshes

Adv. Water Resour., 32 (2009), pp. 439-449 